\title{
Dynamics in bacterioplankton production in a shallow, temperate lake (Lake Neusiedl, Austria): evidence for dependence on macrophyte production rather than on phytoplankton
}

\author{
Bettina Reitner ${ }^{1}$, Alois Herzig ${ }^{2}$, Gerhard J. Herndl ${ }^{3, *}$ \\ ${ }^{1}$ Institute of Zoology, University of Vienna, Althanstr. 14, 1090 Vienna, Austria \\ ${ }^{2}$ Biologische Station Neusiedler See, 7142 Illmitz, Austria \\ ${ }^{3}$ Dept of Biological Oceanography, Netherlands Institute for Sea Research (NIOZ), PO Box 59, 1790 AB Den Burg, Texel, \\ The Netherlands
}

\begin{abstract}
The seasonal dynamics in bacterioplankton abundance and production were studied at 3 characteristic stations (open water, large pond within the reed belt and within the reed Phragmites australis) in the shallow Lake Neusiedl, Austria, and related to phytoplankton primary production and dissolved organic carbon (DOC). DOC concentrations ranged from about 1 to $2.5 \mathrm{mmol}^{-1}$ with humic DOC contributing between $40 \%$ during the winter and $55 \%$ during the summer. Phytoplankton production was highest in the pond within the reed belt, where the attenuation was lowest, reaching $110 \mathrm{mg} \mathrm{C} \mathrm{m}^{-2} \mathrm{~d}^{-1}$ during a distinct phytoplankton bloom in August. Bacterial abundance ranged from $2 \times 10^{6}$ cells $\mathrm{ml}^{-1}$ during winter to about $10 \times 10^{6}$ cells $\mathrm{ml}^{-1}$ during summer. Bacterial production calculated by thymidine (TdR) and leucine (leu) incorporation, respectively, were in good agreement at the stations in the reed belt, but bacterial production based on leu incorporation was significantly lower than bacterial production based on TdR incorporation at the open water station. Based on a bacterial growth yield of $16 \%$ determined in an earlier study, bacterioplankton carbon demand was always at least 1 order of magnitude higher than carbon production of phytoplankton, indicating that bacterioplankton metabolism in Lake Neusiedl is heavily dependent on non-phytoplankton sources of DOC. The bacterial carbon demand (ranging from 225 to $870 \mathrm{mg} \mathrm{C} \mathrm{m}^{-2} \mathrm{~d}^{-1}$ depending on the sampling site and substrate used) could be matched by the production of the reed $P$. australis amounting to 750 to $4510 \mathrm{mg} \mathrm{C} \mathrm{m}{ }^{-2} \mathrm{~d}^{-1}$. Since there is no major allochthonous organic matter input from other sources, this macrophyte production is obviously channeled to the pelagic food web via the bacterioplankton.
\end{abstract}

KEY WORDS: Shallow lake $\cdot$ Bacteria Phytoplankton $\cdot$ Reed $\cdot$ Phragmites Dissolved organic matter Humic substances

\section{INTRODUCTION}

Bacterioplankton are closely linked to phytoplankton via the release of dissolved organic carbon (DOC) from phytoplankton either directly via extracellular release or indirectly via viral lysis or grazing of herbivorous zooplankton (Lampert 1978, Azam et al. 1983,

\footnotetext{
•Addressee for correspondence. E-mail: herndl@nioz.nl
}

Peduzzi \& Herndl 1992). Recently it has also been shown that grazing activity of protists contributes significantly to the production of DOC (Tranvik 1994, Strom et al. 1997). This close trophic dependence of bacterioplankton activity on phytoplankton has been shown in numerous studies for marine and large lotic systems (Chróst 1986, Riemann \& Søndergaard 1986, Vadstein et al. 1989, Weisse et al. 1990, Caron 1994, Ducklow et al. 1995). DOC supply for bacterioplankton growth in small lotic and lentic systems is mediated to 
a large extent by non-phytoplankton or allochthonous sources (Servais \& Garnier 1990, Cotner \& Wetzel 1992, Hudson et al. 1992, Berger et al. 1995, Fiebig 1995, Mann \& Wetzel 1996). With decreasing volume of the water body, the autochthonous DOC production from non-phytoplankton sources becomes increasingly important for the system's metabolism (Wetzel 1992). Findlay et al. (1992), for example, estimated that in the Hudson Estuary, the amount of allochthonous carbon input needed to support bacterial productivity is 3 to 6 times the net carbon fixation by phytoplankton. Coveney \& Wetzel (1995) arrived at a similar conclusion in their detailed study of Lawrence Lake. The net heterotrophic pelagic system was fueled by periphytic and macrophytic production.

The shallow Lake Neusiedl (mean depth $1.1 \mathrm{~m}$ ), Austria, is characterized by a large reed belt of Phragmites australis covering about $55 \%$ of the total lake surface (Löffler 1979), and low transparency of the water column due to wind-induced resuspension limiting the availability of light for phytoplankton production (Dokulil 1994). Nevertheless, the pelagic food web is welldeveloped with large standing stocks of protists and mesozooplankton (Herzig 1979). Thus, one might assume that bacteria, and not phytoplankton, provide the base for the pelagic food web. Heterotrophic bacteria, in turn, might utilize the DOC becoming available from the reed $P$. australis and its periphytes. Water exchange between the reed belt and the open areas is crucial to support bacterial activity in the open water and, indirectly, the pelagic food web. Measuring the DOC dynamics in the open waters and within the reed belt might provide insight into the dynamic exchange processes. Large differences in the concentration of DOC and bacterioplankton activity between the reed belt and the open waters indicate low exchange, while a more even distribution of DOC and bacterial production might indicate rapid exchange processes. Another explanation for an evenly distributed DOC concentration and bacterial activity, however, could be that wind-induced mixing provides DOC from porewater of the sediment to the open water bacteria. Wind-induced resuspension is rather limited in the reed belt. If the pelagic production (phytoplankton and bacteria) is driven by wind-induced input of nutrients from the porewater of the sediment, and not via exchange processes between the reed belt and the open water, the pattern in phytoplankton and bacterial production would not covary between the 2 sites.

In order to decipher the connectivity between the reed belt and the open waters of the shallow, eutrophic Lake Neusiedl, we compared the DOC concentrations and the microbial community and activity at 3 different sites (the open waters, the waters within the reed belt and an open pond in the reed belt) over a year. At all
3 stations, bacterial carbon demand exceeded phytoplankton production by more than 1 order of magnitude, indicating the importance of non-phytoplanktonderived DOC for bacterioplankton metabolism in Lake Neusiedl.

\section{MATERIALS AND METHODS}

Sampling location. A detailed description of the limnology of Lake Neusiedl is given in Löffler (1979). Briefly, Lake Neusiedl (47 $\left.47^{\circ} \mathrm{N}, 16^{\circ} 46^{\prime} \mathrm{E}\right)$ is the largest shallow, alkaline brown-water lake in central Europe $\left(115 \mathrm{~m}\right.$ a.s.l., surface area $321 \mathrm{~km}^{2}$, maximum depth $1.8 \mathrm{~m}$, mean depth $1.1 \mathrm{~m}, \mathrm{pH} 8.5$ to 9.1). About $55 \%$ of the lake is covered by the reed Phragmites australis $\left(178 \mathrm{~km}^{2}\right)_{i}$ within this reed belt, there are numerous reedless ponds of variable size. The water level of the lake is controlled by precipitation (500 to $700 \mathrm{~mm} \mathrm{yr}^{-1}$ ) and evaporation. Frequent resuspension of the sediment caused by winds and currents results in a high concentration of suspended solids in the water column during the ice-free period (Secchi depth $\approx 0.2 \mathrm{~m}$ ); during winter, when the lake is ice-covered for up to $3 \mathrm{mo}$, the concentration of the suspended solids declines due to the reduced water column turbulence. Reedless ponds within the reed belt, such as the Ruster Poschn (surface area $40000 \mathrm{~m}^{2}$ ) are more sheltered from wind-induced mixing and resuspension of the sediments and exhibit therefore a higher transparency (Secchi depth $\approx 0.6 \mathrm{~m}$ ). Due to the shallow water column of Lake Neusiedl, water temperature can change rapidly in spring and fall.

Sampling. Water samples were taken with cleaned ( $1 \mathrm{~N} \mathrm{HCl}$, and rinsed 3 times with water from the sampling site) 51 polycarbonate flasks at 3 characteristic stations, at weekly to 4 -weekly intervals, from November 1996 to October 1997. Stn L (Lake) represents the open lake, and Stn RP (Ruster Poschn) is in the center of a reedless pond within the reed belt. At these 2 stations, samples were taken from $0.5 \mathrm{~m}$ depth. The other sampling station was located within the reed belt ( $\operatorname{Stn} R$ ). There, water samples were taken at $0.2 \mathrm{~m}$ depth (water column depth $0.5 \mathrm{~m}$ ). During sampling, water temperature was measured in the surface $(0.2 \mathrm{~m}$ depth) and bottom layer $(0.2 \mathrm{~m}$ above bottom at the 2 open water stations) and the photosynthetic active radiation (PAR, 400 to $700 \mathrm{~nm}$ ) at $10 \mathrm{~cm}$ depth intervals was measured with a LiCor 1000 radiometer. From these radiation measurements, attenuation coefficients were calculated for each station. The collected water was stored in an isolated box in the dark and brought back to the laboratory (Biological Station Illmitz) within $30 \mathrm{~min}$.

Chlorophyll $a$ and phaeophytin. We filtered 200 to $1500 \mathrm{ml}$ of the water sample onto Whatman GF/F 
(glass fiber) filters (47 $\mathrm{mm}$ filter diameter) and stored frozen $\left(-20^{\circ} \mathrm{C}\right)$ in glass scintillation vials until analysis. Pigments were extracted from the filters in $10 \mathrm{ml}$ of $90 \%$ acetone at $4^{\circ} \mathrm{C}$ overnight and the pigment concentration estimated spectrophotometrically with a Merck-Hitachi U 2000, using the equations given in Parsons et al. (1984). For the determination of the phaeopigments, the solution was acidified with 2 drops of $2 \mathrm{~N} \mathrm{HCl}$ and the absorbance measured again (Parsons et al. 1984).

Phytoplankton primary production. Phytoplankton primary production was measured by the uptake of radiolabeled ${ }^{14} \mathrm{C}$-sodium bicarbonate and its subsequent conversion into organic carbon. We poured $50 \mathrm{ml}$ subsamples through a $62 \mu \mathrm{m}$ mesh (to remove potential grazers) into $\mathrm{HCl}$-rinsed BOD-flasks to which $1 \mu \mathrm{Ci} \mathrm{Na}\left(\mathrm{H}^{14} \mathrm{CO}_{3}\right)_{2}$ (Amersham) was added. Bottles were incubated in duplicates in an outdoor tank filled with lake water and exposed to $100,50,30$, and $10 \%$ of surface solar radiation at in situ temperature from dawn to dusk with 2 dark controls (wrapped in aluminum foil). After incubation, the samples were filtered onto $0.45 \mu \mathrm{m}$ pore-size cellulose nitrate filters (Millipore HAWP, $25 \mathrm{~mm}$ diameter) and rinsed with $10 \mathrm{ml}$ of $0.45 \mu \mathrm{m}$ filtered lake water. Thereafter, the filters were exposed to a fume of concentrated $\mathrm{HCl}$ for $2 \mathrm{~h}$ to remove inorganic carbon and placed in scintillation vials. Filters were dissolved in $1 \mathrm{ml}$ ethyl acetate (Riedel de Haen), and $8 \mathrm{ml}$ scintillation cocktail (Packard Insta plus gel) was added. After $10 \mathrm{~h}$, radioactivity was measured using a Packard Tri-Carb 2000 scintillation counter with external standard ratio technique for sample quenching. For calculating primary production, the mean disintegrations per minute $(\mathrm{dpm})$ of the dark controls was subtracted from the mean dpm of the light-exposed treatments at each radiation level. Estimates of phytoplankton primary production of the respective water column were obtained by integrating the measured daily production at the different radiation levels over the water column.

Enumeration of bacteria. Twenty $\mathrm{ml}$ subsamples were fixed with concentrated formalin $(2 \% \mathrm{v} / \mathrm{v}$, final conc.); depending on the bacterial abundance, 1 to $6 \mathrm{ml}$ were used to enumerate bacterial abundance by DAPI staining and epifluorescence microscopy at $1250 \times$ magnification (Porter \& Feig 1980). Bacterial abundance was enumerated on duplicate subsamples. At least 300 bacteria were counted per filter. Bacterial abundance was converted into bacterial carbon biomass assuming a carbon content of $20 \mathrm{fg} \mathrm{C}^{\mathrm{C}} \mathrm{cell}^{-1}$ (Lee \& Fuhrman 1987).

Measurement of bacterial activity. Bacterial activity was assessed by measuring the incorporation of $\left[{ }^{3} \mathrm{H}\right]-$ thymidine (Amersham, SA $=85 \mathrm{Ci} \mathrm{mmol}^{-1}, 20 \mathrm{nM}$ final conc.) into bacterial DNA (Fuhrman \& Azam 1982) and $\left[{ }^{3} \mathrm{H}\right]$-leucine (Amersham, SA $=131 \mathrm{Ci} \mathrm{mmol}{ }^{-1}, 10 \mathrm{nM}$ final conc.) into bacteria (Simon \& Azam 1989). Five ml subsamples were incubated in triplicates with 2 formalin-killed controls for 30 to $90 \mathrm{~min}$ (depending on the in situ temperature) at in situ temperature in the dark. After incubation, the subsamples were filtered onto cellulose nitrate filters (Millipore, HAWP $0.45 \mu \mathrm{m}$ $25 \mathrm{~mm}$ filter diameter) and rinsed 3 times with $5 \%$ chilled TCA for $5 \mathrm{~min}$. Radioactivity of the filters was measured after adding $1 \mathrm{ml}$ ethyl acetate (Riedel de Haen) and $8 \mathrm{ml}$ scintillation cocktail (Packard Insta plus gel); after $10 \mathrm{~h}$, radioactivity was measured as described above. Thymidine (TdR) incorporation into the bacterial cells was converted into bacterial cell production using the conversion factor of $1.8 \times 10^{18}$ cells produced $\mathrm{mol}^{-1} \mathrm{TdR}_{\text {; }}$ for leucine (leu) a factor of $0.07 \times 10^{18}$ cells $\mathrm{mol}^{-1}$ leu was used (Reitner et al. 1997a). These conversion factors were determined in dilution cultures with water collected from Stn RP over a seasonal cycle by measuring the TdR and leu incorporation into bacteria during their exponential growth in the absence of grazers.

Fractionation of DOC into humic and non-humic components. Only water collected at Stn L was fractionated into humic and non-humic DOC. Upon return to the laboratory, $1.5 \mathrm{l}$ of the water collected at Stn $\mathrm{L}$ was filtered through combusted $\left(450^{\circ} \mathrm{C}\right.$ for $\left.4 \mathrm{~h}\right)$ Whatman GF/F filters (100 mm diameter) mounted in a combusted glass filter holder; thereafter, the $\mathrm{pH}$ of the water was measured and $10 \mathrm{ml}$ of the sample withdrawn, acidified and stored at $-20^{\circ} \mathrm{C}$ for subsequent DOC analysis (described below). All the glassware used was thoroughly acid-washed (with $1 \mathrm{~N} \mathrm{HCl}$ ), rinsed with double-distilled water and combusted $\left(450^{\circ} \mathrm{C}\right.$ for $\left.4 \mathrm{~h}\right)$.

From the $1.5 \mathrm{l}$ of the Whatman GF/F-filtered water, 0.51 was fractionated into a humic and a non-humic fraction of the DOC using macroporous Amberlite XAD-8 resin according to the method described in detail elsewhere (Aiken 1985, Moran \& Hodson 1990, Reitner et al. 1997b). Briefly, the water was adjusted to pH 2 with $6 \mathrm{~N} \mathrm{HCl}$ and poured through a column filled with Amberlite XAD-8 resin and subsequently eluted with $200 \mathrm{ml}$ of $0.1 \mathrm{~N} \mathrm{NaOH}_{\text {; }}$ in this paper we define the humic fraction of the DOC as material retained by the macroporous resin Amberlite XAD-8 at pH 2 and subsequently eluted with $0.1 \mathrm{~N} \mathrm{NaOH}$. Previous studies have shown that the humic fraction isolated with Amberlite XAD- 8 is similar to those isolated by other methods (Peuravuori et al. 1997). Both the DOC fraction not retained by the XAD- 8 resin (considered as the non-humic fraction) and the fraction eluted from the XAD- 8 resin were adjusted to $\mathrm{pH} 10$ and poured through a cationic exchange column filled with Amberlite IR-118H. Water flow through the columns was 
adjusted to a rate of $\sim 40 \mathrm{ml} \mathrm{min}{ }^{-1}$. Subsequently, the humic and the non-humic fraction of the DOC were adjusted to the original $\mathrm{pH}$ with $6 \mathrm{~N} \mathrm{HCl}$ and $2 \mathrm{~N} \mathrm{NaOH}$ and brought up to the original volume with $0.2 \mu \mathrm{m}$ filtered double-distilled water. Thereafter, samples for DOC analysis were taken from the humic and the non-humic fraction, as well as from the doubledistilled water, acidified to $\mathrm{pH} 2$ with $50 \mu \mathrm{l}$ of $6 \mathrm{~N} \mathrm{HCl}$ and stored frozen $\left(-20^{\circ} \mathrm{C}\right)$ together with the acidified unfractionated DOC samples in combusted glass scintillation vials with Teflon-lined caps until DOC analysis. Acidification of the water before freezing the samples prevented precipitation and flocculation in the samples and therefore greatly improved the reproducibility of replicate DOC measurements (Reitner et al. $1997 \mathrm{~b}$ ).

Determination of DOC. The acidified samples were completely thawed and the DOC content was determined using a Shimadzu TOC-5000 after sparging the samples with $\mathrm{CO}_{2}$-free air. Standards were prepared with potassium hydrogen phthalate (Kanto Chemical Co. Inc.); a platinum catalyst on quartz was used (Benner \& Hedges 1993, Reitner et al. 1997b). Five replicate measurements were performed per sample. The overall analytical precision was always better than $3 \%$.

Absorption of DOC. The absorbance characteristics of the DOC were measured against double-distilled water at 250 and $365 \mathrm{~nm}$ and, additionally, scans from 500 to $250 \mathrm{~nm}$ (data not shown) were made using a Beckman DU 640-I and a $5 \mathrm{~cm}$ quartz cuvette. The absorption ratio between 250:365 nm was calculated in order to determine possible differences and shifts in the molecular size spectrum of the DOC between the sampling stations and over the investigation period (Stewart \& Wetzel 1980, 1981).

\section{RESULTS}

\section{Temperature regime and PAR attenuation}

Over the entire investigation period, water temperature varied between 0.1 and $23.7^{\circ} \mathrm{C}$. The ice cover lasted from the end of December to February, reaching its maximum thickness $(28 \mathrm{~cm})$ in early February. During the ice cover, the near bottom waters of Stns $\mathrm{L}$ and $\mathrm{RP}$ were about $1^{\circ} \mathrm{C}$ warmer than the surface water layers underneath the ice. The entire water column of Stn $R$ (within the reed belt) was frozen during January and February. The smallest seasonal variation of the attenuation coefficient (1.22 to $4.47 \mathrm{~m}^{-1}$, mean $\pm \mathrm{SD}=$ $2.24 \pm 0.68 \mathrm{~m}^{-1}, \mathrm{n}=22$ ) was found at $\mathrm{Stn} R P$, which is largely protected from wind-induced sediment resuspension, while Stn L showed the largest variability (1.39 to $14.71 \mathrm{~m}^{-1}$, mean $\left.\pm \mathrm{SD}=4.96 \pm 3.20 \mathrm{~m}^{-1}, \mathrm{n}=22\right)$.
The attenuation coefficient for $\mathrm{Stn} R$ ranged from 1.80 to $10.13 \mathrm{~m}^{-1}$ (mean $\left.\pm \mathrm{SD}=4.04 \pm 2.45 \mathrm{~m}^{-1}, \mathrm{n}=19\right)$.

\section{DOC dynamics}

The absorption ratios, between 250:365 $\mathrm{nm}$, of the unfractionated DOC for the different sampling sites were highest at Stn L (mean \pm SD: $9.72 \pm 1.07$, range: 7.89 to $13.03, \mathrm{n}=22$ ) and lowest at $\mathrm{Stn} \mathrm{R}$ (mean $\pm \mathrm{SD}$ : $6.87 \pm 0.72$, range: 5.84 to $8.27, n=18$ ) (Fig. $1 \mathrm{~A}$ ). The absorption ratios of Stn RP were between the ratios of the other 2 stations (mean $\pm \mathrm{SD}: 8.30 \pm 0.59$, range: 7.13 to $9.54, \mathrm{n}=22$ ) (Fig. 1A). All the site-specific absorption ratios were significantly different from each other (ANOVA, Bonferroni, $\mathrm{p}<0.0001$ ). There were no distinct seasonal dynamics detectable for Stns L and RP; however, at Stn $\mathrm{R}$, the absorption ratio declined from spring to August (Fig. 1A).

Generally, DOC concentrations were lowest and flucuated only over a small range at Stn $\mathrm{L}$ (mean $\pm \mathrm{SD}$ : $1.24 \pm 0.17 \mathrm{mmol} \mathrm{C} \mathrm{l}^{-1}$, range: 1.03 to $1.64 \mathrm{mmol} \mathrm{C} \mathrm{l}^{-1}$, $\mathrm{n}=22$ ), and slightly higher with a larger seasonal variation at Stn RP (mean $\pm \mathrm{SD}: 1.36 \pm 0.35 \mathrm{mmol} \mathrm{C}{ }^{-1}$, range: 0.96 to $2.47 \mathrm{mmol} \mathrm{C} \mathrm{l} \mathrm{l}^{-1}, \mathrm{n}=22$ ) (Fig. 1B). At Stn $R$, within the reed belt, DOC concentrations were siginificantly higher (ANOVA, Bonferroni, $p<0.0001$, $\mathrm{n}=10$ ) than at the 2 other stations during the vegetation period of the reed Phragmites australis (mean $\pm \mathrm{SD}$ : $1.50 \pm 0.17 \mathrm{mmol} \mathrm{C} \mathrm{l}^{-1}$, range: 1.22 to $1.84 \mathrm{mmol} \mathrm{Cl}^{-1}$, $\mathrm{n}=19$ ) (Fig. 1B).

Fractionation of the bulk DOC from Stn L into the humic and non-humic fractions resulted in an average recovery of $95.6 \pm 7.8 \%$ (range: 84.2 to $113.6, n=21$ ) of the unfractionated bulk DOC. The mean contribution of humic substances to the total DOC was $46.1 \pm 5.4 \%$ (range: 36.9 to $55.4 \%, \mathrm{n}=21$ ), or in terms of carbon, $0.57 \pm 0.10 \mathrm{mmol} \mathrm{C} \mathrm{l}^{-1}$ (range: 0.38 to $0.76 \mathrm{mmol} \mathrm{C} \mathrm{l}^{-1}$, $\mathrm{n}=21$ ) (Fig. 1C). Generally, DOC concentrations declined from winter to the end of August (Fig. 1C). The contribution of humic DOC to the bulk DOC was around $45 \%$ during the winter, increased in spring to a maximum of $55 \%$ and declined again in early fall (Fig. 1C). The concentration of the non-humic DOC ranged from 0.40 to $0.85 \mathrm{mmol} \mathrm{C}^{-1}$ (mean $\pm \mathrm{SD}$ $0.61 \pm 0.13 \mathrm{mmol} \mathrm{C} \mathrm{l} \mathrm{C}^{-1}, \mathrm{n}=21$ ).

\section{Seasonal dynamics of phytoplankton biomass and production}

Phytoplankton biomass measured as chlorophyll a (chl a) concentration ranged from 2.14 to $17.10 \mu \mathrm{g} \mathrm{chl} \mathrm{a}$ $\mathrm{l}^{-1}$ at Stn RP (mean $\pm \mathrm{SD}: 5.85 \pm 3.47 \mu \mathrm{g} \mathrm{chl} \mathrm{a} \mathrm{I}^{-1}$ ), at Stn R from 2.44 to $10.32 \mu \mathrm{g} \mathrm{chl} \mathrm{a}^{-1}$ (mean \pm SD: $5.12 \pm 1.97 \mu \mathrm{g}$ 

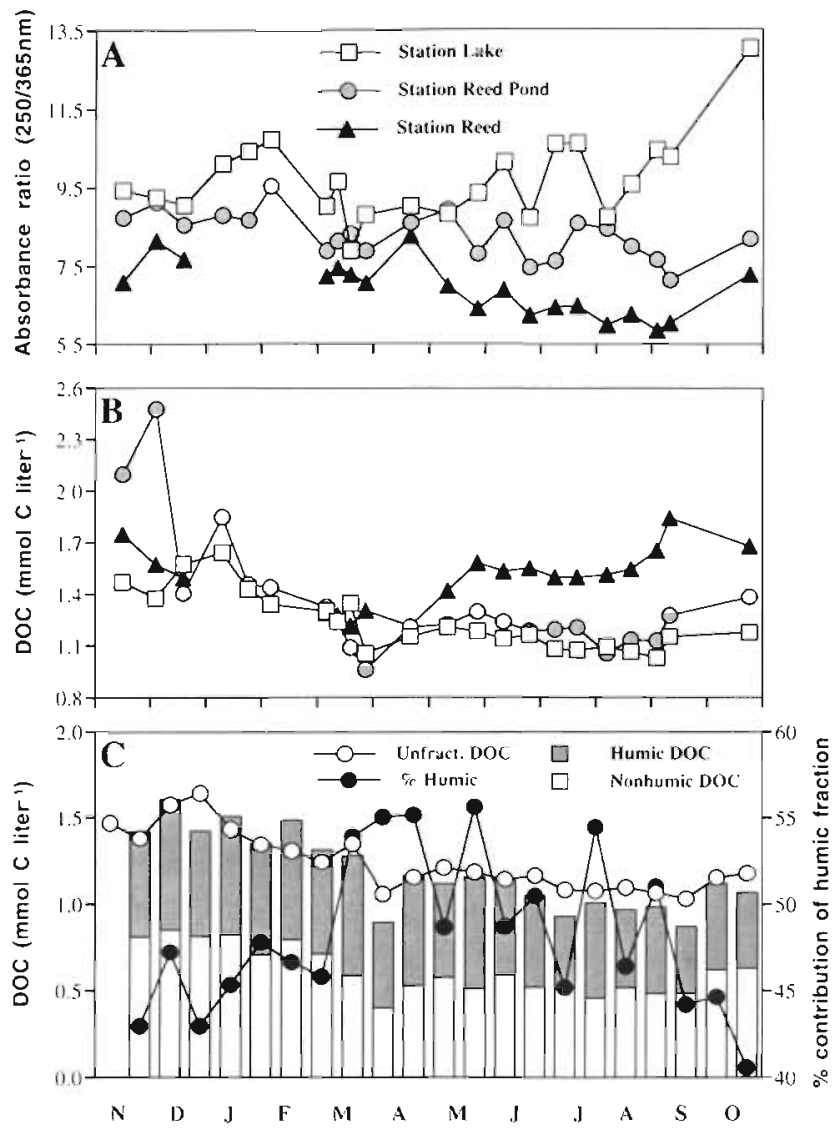

Fig. 1 DOC dynamics at the 3 sampling sites in the Lake Neusiedl over the study period from November 1996 through October 1997. (A) Absorption ratio of 250:365 nm wavelength; (B) total DOC concentration; and (C) distribution of humic and non-humic DOC and the \% contribution of the humic DOC to the total DOC (right axis); for comparison, the total, unfractionated DOC concentration is also given

chl $a \mathrm{l}^{-1}$ ) and was slightly higher at Stn L (mean $\pm \mathrm{SD}$ :

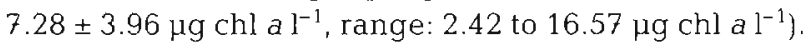
From March until June, Stn L was characterized by generally high chl a concentrations, while at Stn RP highest chl a concentrations were reached in January and March (Fig. 2A). No site-specific significant differences in the chl a concentrations were detectable (ANOVA, Bonferroni, $p>0.0589$ ). Concentrations of phaeopigments varied considerably over the seasonal cycle (Stn L: $0.77 \pm$ $1.05 \mu \mathrm{g} \mathrm{l}^{-1}$, Stn RP: $1.65 \pm 1.35 \mu \mathrm{g} \mathrm{l}^{-1}$, and Stn R: $1.15 \pm$ $1.43 \mu \mathrm{gl}^{-1}$ ) (data not shown).

Mean primary production integrated over the water column was $16.59 \pm 14.93 \mathrm{mg} \mathrm{C} \mathrm{m}^{-2} \mathrm{~d}^{-1}$ for Stn $\mathrm{L}, 19.81$ $\pm 25.54 \mathrm{mg} \mathrm{C} \mathrm{m}^{-2} \mathrm{~d}^{-1}$ for Stn RP, and $1.94 \pm 3.74 \mathrm{mg} \mathrm{C}$ $\mathrm{m}^{-2} \mathrm{~d}^{-1}$ for Stn R (Fig. 2B). Two pronounced peaks in phytoplankton production were found for the open water Stns L and RP: a first smaller peak after the ice melt in mid-March, and a large peak in mid-August. The latter peak in primary production was also detec- table, although not as pronounced, at Stn R (Fig. 2B) This peak in activity is also reflected in the specific productivity (Fig. 2C), indicating that highly active cells at comparatively low concentrations were responsible for the high phytoplankton production rates in August. This high production coincided with a shift in the phytoplankton community. While the abundance of the cyanobacterium Microcystis sp. declined in August by about 1 order of magnitude, the abundance of Chrysophyceae remarkably increased (data not shown).

\section{Seasonal dynamics of bacterial abundance and activity}

Bacterial abundance (Fig. $3 \mathrm{~A}$ ) at the 3 stations showed similar fluctuations throughout the annual cycle, with lowest abundances at low water temperatures. At Stn L, $73 \%$ of the fluctuations of bacterial abundance could be explained by water temperature; at Stns RP and R, this was 59 and $57 \%$, respectively. The highest mean bacterial abundance was observed at Stn R (mean $\pm \mathrm{SD}=59.4 \pm 26.9 \times 10^{5}$ cells ml ${ }^{-1}$, range: 21.1 to $116.0 \times 10^{5} \mathrm{ml}^{-1}, \mathrm{n}=19$ ). At $\mathrm{Stn} \mathrm{RP}$, the abundance varied from 22.4 to $132.4 \times 10^{5} \mathrm{ml}^{-1}$ (mean $\left.\pm \mathrm{SD}=56.6 \pm 26.6 \times 10^{5} \mathrm{ml}^{-1}, \mathrm{n}=22\right)$ and the lowest mean bacterial abundance (mean $\pm \mathrm{SD}=51.7 \pm 16.9 \times$ $10^{5}$ cells ml ${ }^{-1}$, range: 24.8 to $81.6 \times 10^{5} \mathrm{ml}^{-1}, \mathrm{n}=22$ ) was recorded for Stn L (Fig. 3A).

Bacterial production calculated from TdR incorporation measurements showed the expected, distinct seasonal pattern with low production during the winter (lowest production at Stn L: $5.3 \mu \mathrm{g} \mathrm{Cl}^{-1} \mathrm{~d}^{-1}$ ) and a rapid increase after the melting of the ice by the end of March, and consistently high rates during summer (between 100 and $300 \mathrm{\mu g} \mathrm{C} \mathrm{l}^{-1} \mathrm{~d}^{-1}$ for all 3 stations) (Fig. 3B). Averaging bacterial production over the seasonal cycle estimated from $\mathrm{TdR}$ and leu incorporation measurements, respectively, indicated that bacterial production estimated by the 2 methods were not significantly different from each other for Stns RP and R (Fig. 3B,C) although the 2 measurements did not always exhibit the same tendency. Mean bacterial production estimated by $\mathrm{TdR}$ and leu incorporation was for Stn RP $126.0 \pm 76.4 \mu \mathrm{g} \mathrm{Cl}^{-1} \mathrm{~d}^{-1}$ and $110.0 \pm$ $49.0 \mu \mathrm{g} \mathrm{Cl}^{-1} \mathrm{~d}^{-1}$, respectively, for Stn R $126.9 \pm 68.9 \mu \mathrm{g}$ $\mathrm{Cl}^{-1} \mathrm{~d}^{-1}$ and $119.4 \pm 80.8 \mu \mathrm{g} \mathrm{Cl}^{-1} \mathrm{~d}^{-1}$, and for Stn $\mathrm{L}$, $102.5 \pm 70.5 \mu \mathrm{g} \mathrm{C} \mathrm{l}^{-1} \mathrm{~d}^{-1}$ and $46.7 \pm 34.4 \mu \mathrm{g} \mathrm{C} \mathrm{l}^{-1} \mathrm{~d}^{-1}$, and therefore significantly lower for leu than for $T d R$ (Wilcoxon, $\mathrm{p}<0.001$ ).

Bacterial growth rates determined from $T d R$ and leu incorporations exhibited large variations over the seasons, ranging from 0.05 to $2.57 \mathrm{~d}^{-1}$ for all sampling sites; the mean annual bacterial growth rate based on TdR incorporation was $0.91 \pm 0.51 \mathrm{~d}^{-1}$ for Stn $\mathrm{L}, 1.09 \pm$ 

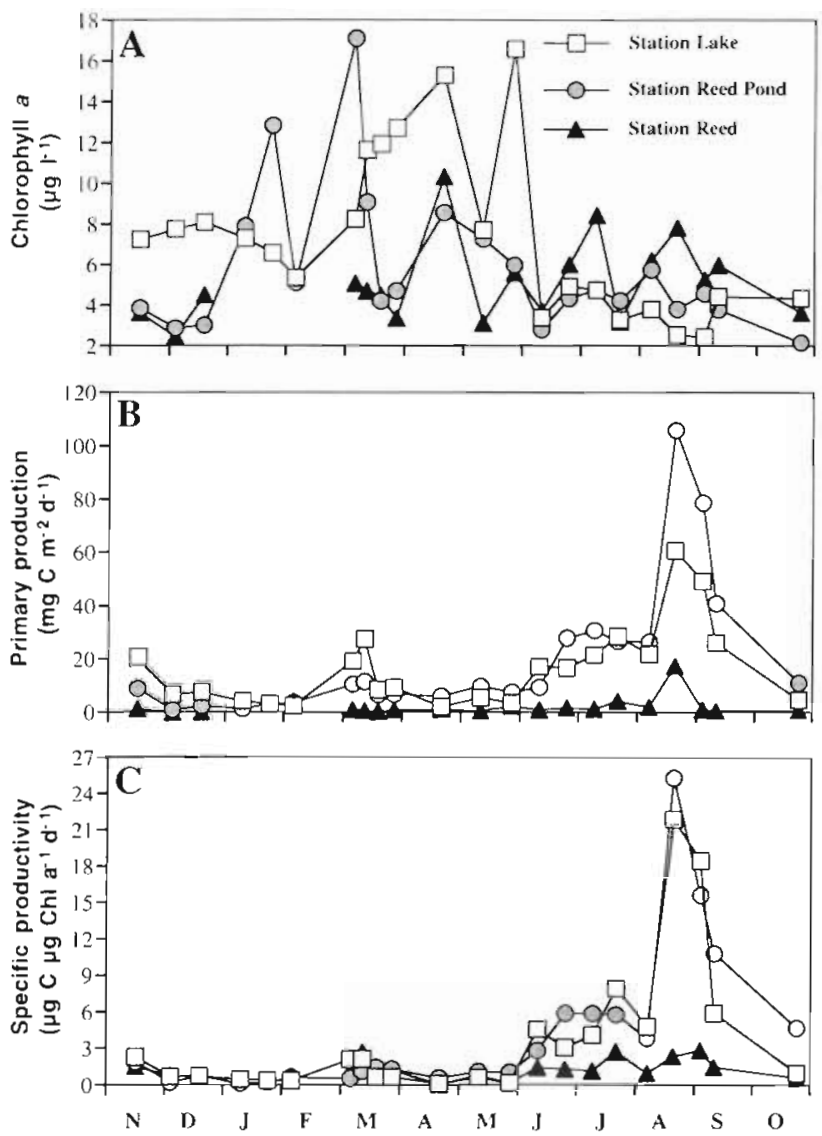

Fig. 2. Phytoplankton dynamics at the 3 stations in Lake Neusiedl over the investigation period. (A) Chlorophyll a concentrations; (B) phytoplankton production; and (C) phytoplankton specific productivity

$0.54 \mathrm{~d}^{-1}$ for Stn RP and $1.06 \pm 0.42 \mathrm{~d}^{-1}$ for Stn $R$ (Fig. 3D). Mean bacterial growth rates based on leu incorporation were for Stn L $0.45 \pm 0.34 \mathrm{~d}^{-1}$, for Stn RP $1.05 \pm 0.51 \mathrm{~d}^{-1}$, and for Stn R $0.99 \pm 0.61 \mathrm{~d}^{-1}$. Bacterial growth rates were significantly lower at Stn $\mathrm{L}$ for both leu and $T d R$ as compared to the more sheltered Stns RP and R (Wilcoxon, $\mathrm{p}<0.001, \mathrm{n}=19$, for both).

The molar ratio of leu:TdR incorporation was $15.5 \pm$ 10.8 (range: 3.8 to $42.6, n=22$ ) for Stn $L, 33.2 \pm 25.4$ (range: 6.1 to $126.6, \mathrm{n}=22$ ) for $S t n R P$ and $27.5 \pm 16.8$ (range: 3.7 to $69.3, \mathrm{n}=19$ ) for $\mathrm{Stn} \mathrm{R}$, and therefore significantly higher at Stns RP and R (Wilcoxon, $p<0.001$, $n=19$, for both) than at Stn L (Fig. 4). Generally, higher molar leu:TdR incorporation ratios were observed during winter and lower ratios during the summer months (Fig. 4).

\section{DISCUSSION}

The sampling stations used in this study comprised all the characteristic environments of the lake: the
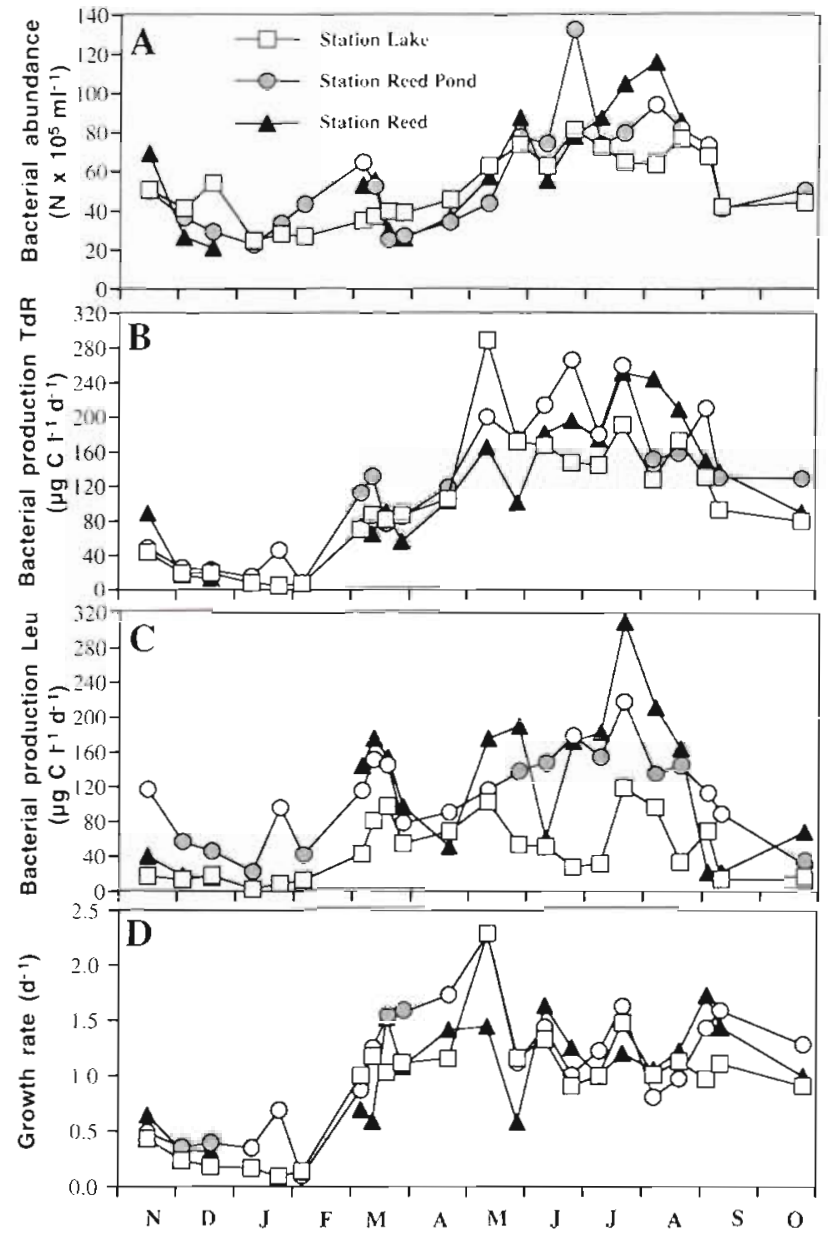

Fig. 3. Fluctuations in (A) bacterial abundance, bacterial production measured by $(B)$ thymidine $(T d R)$ and $(C)$ leucine (Leu) incorporation, and (D) growth rates (bacterial production estimated from TdR incorporation/biomass) at the 3 sampling sites

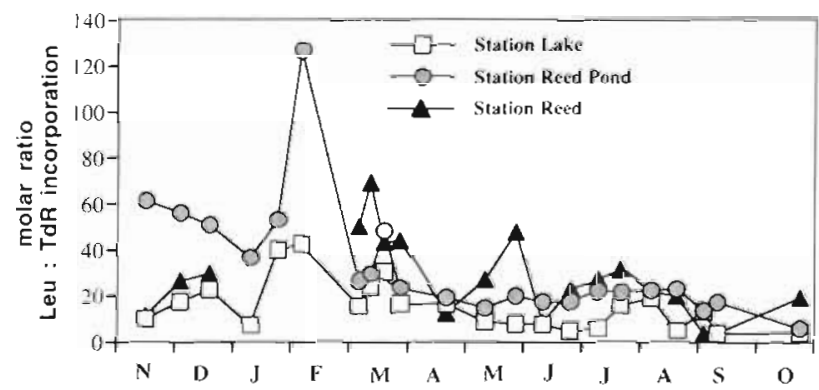

Fig. 4. Dynamics of the molar ratio of Leu:TdR incorporation at the 3 sampling sites over the investigation period

open water, the ponds within the reed belt and the water of the reed belt itself. They are characterized by different turbulence regimes. While mixing in the open water (Stn L) prevents stratification throughout the year, Stn RP is more protected from wind-induced 
turbulence and, consequently, has a lower attentuation of light. Stn $\mathrm{R}$ inside the reed belt is characterized by a shallow water column $(-30 \mathrm{~cm})$ and reduced exchange of water with the open lake. Nevertheless, the development of the phytoplankton bloom in August was detectable at all 3 stations (Fig. 2), indicating that water exchange is sufficient between the open water and the reed belt to allow a concurrent development of plankton blooms in the different subsystems.

Major differences between the 3 subsystems were detectable for DOC. Stn R, within the reed belt, exhibited consistently higher DOC concentrations than the other 2 stations from April to October (Fig. 1B). Also, the absorption ratio of the DOC was significantly lower at $\operatorname{Stn} \mathrm{R}$, indicating a higher fraction of labile DOC than at the other 2 stations. Since the specific production of phytoplankton was lower at Stns RP and L than at Stn R, the higher fraction of labile DOC probably originates from the reed and its epiphytes. Epiphytes might release substantial amounts of extracellular release (Haines et al. 1987, Grimshaw et al. 1997). The higher fraction of labile DOC at Stn R, however, did not cause elevated bacterial abundance and growth rates as compared to Stns RP and L (Fig. 3).

\section{Bacterial versus phytoplankton production}

Mean annual bacterial production based on TdR incorporation for the 3 stations ranged from $38.1 \mathrm{mg} \mathrm{C}$ $\mathrm{m}^{-2} \mathrm{~d}^{-1}$ at Stn $\mathrm{R}$ to $139 \mathrm{mg} \mathrm{C} \mathrm{m} \mathrm{m}^{-2} \mathrm{~d}^{-1}$ at Stn RP and based on leu from 36 to $121 \mathrm{mg} \mathrm{C} \mathrm{m}^{-2} \mathrm{~d}^{-1}$, respectively. Mean annual phytoplankton production ranged from 2 to $20 \mathrm{mg} \mathrm{C} \mathrm{m}^{-2} \mathrm{~d}^{-1}$, at Stns $\mathrm{R}$ and $\mathrm{RP}$, respectively (Table 1). The bacterial growth yield was determined in a previous study (Reitner et al. 1997a) and in a preliminary experiment. While in Reitner et al. (1997a) the bacterial growth yield was estimated from the DOC decline in the ice-covered lake (no DOC input) and the concomitantly performed bacterial incorporation of thymidine over a period of $3 \mathrm{mo}$, in a subsequent exercise during the summer months, bacterial production and respiration were measured in $0.8 \mu \mathrm{m}$ filtrates. Both independent estimates resulted in a bacterial growth yield of $16 \%$. This bacterial growth yield is in the range of growth yields reported from a diverse range of freshwater and marine systems (del Giorgio \& Cole 1998).

Using the growth yield of $16 \%$ determined for Lake Neusiedl (Reitner et al. 1997a), the mean annual bacterial carbon demand at the 3 different stations ranges

Table 1. Summary of bacterial carbon demand (bacterial C demand) at the 3 stations (L: Lake, RP: Reed Pond, R: Reed) of Lake Neusiedl, Austria, based on leucine (Leu) and thymidine (TdR) incorporation measurements, phytoplankton production and the ratio between bacterial carbon demand and phytoplankton production. Bacterial carbon demand was estimated using a bacterial yield of $16 \%$ (Reitner et al. $1997 \mathrm{a}$ ). nd: not determined due to completely frozen water column. Rates are given in mg $\mathrm{C} \mathrm{m}^{-2} \mathrm{~d}^{-1}$

\begin{tabular}{|c|c|c|c|c|c|c|c|c|c|c|c|c|c|c|c|}
\hline \multirow[t]{2}{*}{$\begin{array}{l}\text { Date } \\
(\mathrm{d} / \mathrm{mo} / \mathrm{yr})\end{array}$} & \multicolumn{3}{|c|}{$\begin{array}{c}\text { Bacterial C demand } \\
\text { based on TdR }\end{array}$} & \multicolumn{3}{|c|}{$\begin{array}{c}\text { Bacterial C demand } \\
\text { based on Leu }\end{array}$} & \multicolumn{3}{|c|}{$\begin{array}{l}\text { Primary } \\
\text { production }\end{array}$} & \multicolumn{3}{|c|}{$\begin{array}{c}\text { Bacterial C demand } \mathrm{TdR} \\
\text { primary production }\end{array}$} & \multicolumn{3}{|c|}{$\begin{array}{c}\text { Bacterial C demand Lew } \\
\text { primary production }\end{array}$} \\
\hline & $\mathrm{L}$ & $\mathrm{RP}$ & $\mathrm{R}$ & $L$ & $\mathrm{RP}$ & $\mathrm{R}$ & $\mathrm{L}$ & RP & $\mathrm{R}$ & L & $\mathrm{RP}$ & $\mathrm{R}$ & L & $\mathrm{RP}$ & $\mathrm{R}$ \\
\hline $15 / 11 / 96$ & 303 & 337 & 168 & 119 & 809 & 75 & 20.0 & 8.9 & 1.3 & 15 & 38 & 134 & 6 & 91 & 60 \\
\hline $03 / 12 / 96$ & 135 & 179 & 32 & 92 & 393 & 33 & 6.6 & 0.8 & 0.0 & 20 & 212 & & 14 & 465 & \\
\hline $18 / 12 / 96$ & 137 & 160 & 25 & 1.22 & 318 & 30 & 7.5 & 2.4 & 0.0 & 18 & 66 & 946 & 16 & 131 & 1102 \\
\hline $08 / 01 / 97$ & 57 & 109 & nd & 16 & 156 & nd & 4.2 & 1.4 & $\mathrm{nd}$ & 14 & 79 & nd & 4 & 113 & nd \\
\hline $22 / 01 / 97$ & 36 & 320 & nd & 57 & 662 & nd & 3.2 & 3.1 & nd & 12 & 103 & nd & 18 & 214 & nd \\
\hline $03 / 02 / 97$ & 52 & 58 & nd & 86 & 285 & nd & 2.4 & 3.6 & nd & 22 & 16 & nd & 36 & 80 & nd \\
\hline $05 / 03 / 97$ & 486 & 779 & 139 & 296 & 801 & 272 & 19.1 & 10.4 & 0.9 & 25 & 75 & 148 & 16 & 77 & 288 \\
\hline $11 / 03 / 97$ & 604 & 912 & 123 & 560 & 1047 & 331 & 27.5 & 11.4 & 0.6 & 22 & 80 & 221 & 20 & 92 & 597 \\
\hline $18 / 03 / 97$ & 565 & 533 & 171 & 675 & 1005 & 290 & 8.5 & 6.6 & 0.2 & 66 & 81 & 851 & 79 & 152 & 1438 \\
\hline $26 / 03 / 97$ & 602 & 592 & 107 & 380 & 542 & 183 & 9.2 & 6.7 & 0.8 & 66 & 88 & 126 & 41 & 81 & 216 \\
\hline $16 / 04 / 97$ & 731 & 827 & 196 & 476 & 627 & 96 & 2.2 & 6.0 & 1.0 & 340 & 137 & 196 & 221 & 104 & 97 \\
\hline $05 / 05 / 97$ & 2000 & 1387 & 312 & 710 & 807 & 331 & 5.5 & 9.7 & 0.5 & 367 & 142 & 596 & 130 & 83 & 632 \\
\hline $21 / 05 / 97$ & 1189 & 1206 & 191 & 369 & 946 & 358 & 3.5 & 7.4 & 2.2 & 340 & 162 & 87 & 106 & 127 & 163 \\
\hline $04 / 06 / 97$ & 1160 & 1484 & 343 & 354 & 1015 & 113 & 17.0 & 9.4 & 0.9 & 68 & 158 & 369 & 21 & 108 & 122 \\
\hline $18 / 06 / 97$ & 1023 & 1843 & 370 & 192 & 1234 & 325 & 16.7 & 27.9 & 1.7 & 61 & 66 & 218 & 12 & 44 & 192 \\
\hline $02 / 07 / 97$ & 1002 & 1248 & 330 & 219 & 1065 & 344 & 21.5 & 30.7 & 1.3 & 47 & 41 & 264 & 10 & 35 & 275 \\
\hline $14 / 07 / 97$ & 1325 & 1797 & 475 & 820 & 1507 & 584 & 28.4 & 26.7 & 4.2 & 47 & 67 & 114 & 29 & 56 & 140 \\
\hline $30 / 07 / 97$ & 888 & 1050 & 461 & 667 & 928 & 398 & 21.7 & 26.4 & 1.9 & 41 & 40 & 245 & 31 & 35 & 212 \\
\hline $12 / 08 / 97$ & 1199 & 1099 & 395 & 231 & 995 & 309 & 60.6 & 105.7 & 17.3 & 20 & 10 & 23 & 4 & 9 & 18 \\
\hline $26 / 08 / 97$ & 909 & 1457 & 282 & 477 & 780 & 40 & 49.1 & 78.5 & 0.9 & 19 & 19 & 310 & 10 & 10 & 44 \\
\hline $02 / 09 / 97$ & 644 & 903 & 258 & 94 & 613 & 41 & 26.0 & 40.8 & 0.4 & 25 & 22 & 620 & 4 & 15 & 98 \\
\hline $15 / 10 / 97$ & 554 & 895 & 170 & 90 & 213 & 128 & 4.6 & 10.9 & 0.7 & 120 & 82 & 240 & 19 & 19 & 181 \\
\hline Mean & 709 & 872 & 239 & 323 & 761 & 225 & 16.6 & 19.8 & 1.9 & 81 & 81 & 317 & 39 & 97 & 326 \\
\hline $\mathrm{SD}$ & 488 & 529 & 130 & 238 & 339 & 153 & 14.9 & 25.5 & 3.7 & 110 & 52 & 256 & 51 & 94 & 375 \\
\hline
\end{tabular}


from 240 to $872 \mathrm{mg} \mathrm{C} \mathrm{m}^{-2} \mathrm{~d}^{-1}$ (based on TdR incorporation) and from 225 to $761 \mathrm{mg} \mathrm{C} \mathrm{m}^{-2} \mathrm{~d}^{-1}$ (based on leu incorporation)(Table 1). Therefore, bacterial $\mathrm{C}$ demand is at least 1 order of magnitude higher (39 to 326 times) than the amount of carbon supplied by phytoplankton production. In our measurements of the primary production we did not include the dissolved production, i.e. the release of photosynthetically fixed DOC into the ambient water, which serves as a potential food source for bacterioplankton. Even high release rates of phytoplankton-derived DOC would not match the $C$ demand by bacterioplankton. Release rates are usually reported to be in the range of 0 to $30 \%$ of the photosynthetically fixed carbon (Lignell 1990, Williams 1990, Malinsky-Rushansky \& Legrand 1996) but can be as high as $70 \%$ under P-limited conditions (Kaltenböck \& Herndl 1992, Obernosterer \& Herndl 1995). Thus, in Lake Neusiedl phytoplankton-derived DOC is only of minor importance for bacterioplankton metabolism. Even at Stn L, which reflects the open water conditions of the lake, bacterial C demand was always higher than phytoplankton primary production, even under bloom conditions (at leads $\sim 4$ times, Table 1). Although there is some uncertainty in the bacterial production estimates since we used a single conversion factor for $\mathrm{TdR}$ and Leu, the general conclusion that bacterial $\mathrm{C}$ demand cannot be met by phytoplankton production is robust.

The $\mathrm{C}$ demand for bacterioplankton is therefore likely to be matched by the large-standing crop of Phragmites australis and its periphytes. The primary production of $P$. australis amounts to $1370-8200 \mathrm{mg} \mathrm{C}$ $\mathrm{m}^{-2}$ reed belt $\mathrm{d}^{-1}$ (Kvet \& Husak 1978) and about $55 \%$ of the lake is covered by $P$. australis (Löffler 1979). Calculating the average primary production of $P$. australis for the entire lake, the primary production of the reed amounts to $750-4510 \mathrm{mg} \mathrm{C} \mathrm{m}^{-2} \mathrm{~d}^{-1}$. Therefore, the estimated bacterial $\mathrm{C}$ demand for bacterioplankton ranging from 225 to $870 \mathrm{mg} \mathrm{C} \mathrm{m} \mathrm{C}^{-2}$ (depending on the stations and the substrate used) is only slightly lower than the primary production estimates for $P$. australis (Table 1). The high contribution of this cellulose-rich material to the DOC pool is evident from the data on the contribution of humic material to the bulk DOC (Fig. 1). In a previous study (Reitner et al. 1997a), it was shown that the contribution of humic DOC to bulk DOC declines during the winter. In the present study, the same tendency was found; low humic DOC contribution was detectable during the winter and increased towards the summer to values above $55 \%$ (Fig. 1).

Based on the bacterioplankton $\mathrm{C}$ demand calculated from TdR incorporation measurements, a bacterial growth yield of $16 \%$ (Reitner et al. 1997a) and the DOC concentrations at the 3 different stations, we arrived at a mean DOC turnover time of $86 \mathrm{~d}$ (range:
8 to $519 \mathrm{~d}, \mathrm{n}=22$ ) for Stn L, $57 \mathrm{~d}$ (range: 8 to $328 \mathrm{~d}$, $\mathrm{n}=22$ ) for Stn $\mathrm{RP}$, and $42 \mathrm{~d}$ (range: 11 to $212 \mathrm{~d}, \mathrm{n}=19$ ) for Stn R. Based on leu incorporation, mean turnover times were $150 \mathrm{~d}$ (range: 17 to $1325 \mathrm{~d}, \mathrm{n}=22$ ), $36 \mathrm{~d}$ (range: 11 to $157, \mathrm{n}=22$ ) and $56 \mathrm{~d}$ (range 9 to 182 , $\mathrm{n}=19$ ) for Stns L, RP, and R, respectively. As expected, DOC turnover times were generally higher during the winter season and lower during the summer.

In summary, major differences between the 3 subsystems were found only in the concentration and quality of the DOC. Within the reed belt, DOC concentrations were higher with a higher fraction of the DOC being labile. Since there were no significant differences detectable in phytoplankton chl a concentrations and the specific phytoplankton production between the stations, we concluded that the elevated DOC concentrations within the reed belt originate from the reed and its periphytes. Overall, bacterioplankton metabolism in Lake Neusiedl is always at least 1 order of magnitude higher than phytoplankton production and, therefore, depends on non-phytoplankton-derived DOC, which is probably supplied by the reed Phragmites australis and its periphytes. Thus, the pelagic food web of Lake Neusiedl is based largely on reed (and its periphytes) production; its DOC production is exported into the open waters and supports bacterioplankton growth there. Thus, the basis of the welldeveloped pelagic food web in Lake Neusiedl is bacterioplankton which are preyed upon by protists and possibly also by mesozooplankton. Phytoplankton play only a minor role in suporting the pelagic food web. Future studies should focus on the DOC production of the reed $P$. australis and its periphytes.

Acknowledgements. The continuous support of the staff of the Biological Station Illmitz during the course of the study and of the colleagues at the Institute of Zoology, University of Vienna, is gratefully acknowledged. I. Kolar excellently performed the DOC analyses. Funding support for this research was provided by grants from the Austrian National Bank and the Arbeitsgemeinschaft Neusiedler See (to G.J.H.). This work is part of the fulfillment of the requirements for a $\mathrm{PhD}$ degree from the University of Vienna by B.R.

\section{LITERATURE CITED}

Aiken GR (1985) Isolation and concentration techniques for aquatic humic substances. In: Aiken GR, McKnight DM, Wershaw RL (eds) Humic substances in soil, sediment, and water. Geochemistry, isolation, and characterization. John Wiley \& Sons, New York, p 363-383

Azam F, Fenchel T, Field JG, Gray JS, Meyer-Reil LA, Thingstad $F$ (1983) The ecological role of water-column microbes in the sea. Mar Ecol Prog Ser 10:257-263

Benner R, Hedges JI (1993) A test of the accuracy of freshwater DOC measurements by high-temperature catalytic oxidation and UV-promoted persulfate oxidation. Mar Chem 41:161-165 
Berger B, Hoch B, Kavka G. Herndl GJ (1995) Bacterial metabolism in the River Danube: parameters influencing bacterial production. Freshw Biol 34:601-616

Caron DA (1994) Inorganic nutrients, bacteria, and the microbial loop. Microb Ecol 28:295-298

Chróst RJ (1986) Algal-bacterial metabolic coupling in the carbon and phosphorus cycle in lakes. In: Megusar $F_{\text {, }}$ Gantar M (eds) Perspectives in microbial ecology. Slovene Society of Microbiology, Ljubljana, p 360-366

Cotner JB Jr, Wetzel RG (1992) Uptake of dissolved inorganic and organic phosphorus compounds by phytoplankton and bacterioplankton. Limnol Oceanogr 37:232-243

Coveney MF, Wetzel RG (1995) Biomass, production, and specific growth rate of bacterioplankton and coupling to phytoplankton in an oligotrophic lake. Limnol Oceanogr 40:1187-1200

del Giorgio PA, Cole JJ (1998) Bacterial growth yield efficiency in natural aquatic systems. Annu Rev Ecol Syst 29: 503-541

Dokulil MT (1994) Environmental control of phytoplankton productivity in turbulent turbid systems. Hydrobiologia 289:65-72

Ducklow HW, Quinby HL, Carlson CA (1995) Bacterioplankton dynamics in the equatorial Pacific during the 1992 El Niño. Deep-Sea Res II 42:621-638

Fiebig DM (1995) Groundwater discharge and its contribution of dissolved organic carbon to an upland stream. Arch Hydrobiol 134:129-155

Findlay S, Pace ML, Lints D, Howe K (1992) Bacterial metabolism of organic carbon in the tidal freshwater Hudson Estuary. Mar Ecol Prog Ser 89:147-153

Fuhrman JA, Azam F (1982) Thymidine incorporation as a measure of heterotrophic bacterioplankton production in marine surface waters: evaluation and field results. Mar Biol 66:109-120

Grimshaw HJ, Wetzel RG, Brandenburg $M$, Segerblom $K$, Wnkert LJ, Marsh GA, Charnetzky W, Haky JE, Caraher $C$ (1997) Shading of periphyton communities by wetland emergent macrophytes: decoupling of algal photosynthesis from microbial nutrient retention. Arch Hydrobiol 139: $17-27$

Haines DW, Rogers KH, Rogers FEJ (1987) Loose and firmly attched epiphyton: their relative contributions to algal and bacterial carbon productivity in a Phragmites marsh. Aquat Bot 29:169-176

Herzig A (1979) The zooplankton of the open lake. In: Löffler $\mathrm{H}$ (ed) Neusiedlersee: limnology of a shallow lake in central europe. W Junk, The Hague, p 281-336

Hudson JJ, Roff JC, Burnison BK (1992) Bacterial productivity in forested and open streams in southern Ontario. Can J Fish Aquat Sci 49:2412-2422

Kaltenböck E, Herndl GJ (1992) Ecology of amorphous aggregations (marine snow) in the Northern Adriatic Sea. IV. Dissolved nutrients and the autotrophic community associated with marine snow. Mar Ecol Prog Ser 87: $147-159$

Kvet J, Husak S (1978) Primary data on biomass and production estimates in typical stands of fishponds. In: Dykyjova D, Kvet J (eds) Pond littoral ecosystems. Springer, Berlin, p 211-216

Lampert W (1978) Release of dissolved organic carbon by grazing zooplankton. Limnol Oceanogr 23:831-834

Lee S, Fuhrman JA (1987) Relationships between biovolume and biomass of naturally derived marine bacterioplankton. Appl Environ Microbiol 53:1298-1303

Lignell R (1990) Excretion of organic carbon by phytoplankton: its relation to algal biomass, primary productivity and bacterial secondary productivity in the Baltic Sea. Mar Ecol Prog Ser 68:85-99

Löfler H (1979) Neusiedler See: the limnology of a shallow lake in central Europe. W Junk Publ, The Hague

Malinsky-Rushansky N, Legrand C (1996) Excretion of dissolved organic carbon by phytoplankton of different sizes and subsequent bacterial uptake. Mar Ecol Prog Ser 132: $249-255$

Mann CJ, Wetzel RG (1996) Dissolved organic carbon and its utilization in a riverine wetland ecosystem. Biogeochemistry 31:99-120

Moran MA, Hodson RE (1990) Bacterial production on humic and nonhumic components of dissolved organic carbon. Limnol Oceanogr 35:1744-1756

Obernosterer I, Herndl GJ (1995) Phytoplankton extracellular release and bacterial growth: dependence on the inorganic N:P ratio. Mar Ecol Prog Ser 116:247-257

Parsons T, Maita Y, Lalli C (1984) A manual of chemical and biological methods for seawater analysis. Pergamon Press Oxford

Peduzzi P, Herndl GJ (1992) Zooplankton activity fueling the microbial loop: differential growth response of bacteria from oligo- and eutrophic waters. Limnol Oceanogr 37: $1087-1092$

Peuravuori J, Pihlaja K, Välimäki N (1997) Isolation and characterization of natural organic matter from lake water: two different adsorption chromatographic methods. Environ Int 23:453-464

Porter KG, Feig YS (1980) The use of DAPI for identifying and counting aquatic microflora. Limnol Oceanogr 25:943-948

Reitner B, Herzig A, Herndl GJ (1997a) Microbial activity under the ice cover of a shallow lake. Hydrobiologia 357 : $173-184$

Reitner B, Herzig A, Herndl GJ (1997b) Role of ultraviolet-B radiation on photochemical and microbial oxygen consumption in a humic-rich shallow lake. Limnol Oceanogr $42: 950-960$

Riemann B, Sondergaard M (1986) Regulation of bacterial secondary production in two eutrophic lakes and in experimental enclosures. J Plankton Res 8:519-536

Servais P, Garnier J (1990) Bacterial heterotrophic activity in the River Seine: tritiated thymidine and leucine incorporation profiles. CR Acad Sci Paris 311 (Serie III):353-360

Simon M, Azam F (1989) Protein content and protein synthesis rates of planktonic marine bacteria. Mar Ecol Prog Ser 51:201-213

Stewart AJ, Wetzel RG (1980) Fluorescence:absorbance ratios-a molecular-weight tracer of dissolved organic matter. Limnol Oceanogr 25:559-564

Stewart AJ, Wetzel RG (1981) Asymetrical relationship between absorbance, fluorescence, and dissolved organic carbon. Limnol Oceanogr 26:590-597

Strom SL, Benner R, Ziegler S, Dagg MJ (1997) Planktonic grazers are a potentially important source of marine dissolved organic carbon. Limnol Oceanogr 42:1364-1374

Tranvik L (1994) Colloidal and dissolved organic matter excreted by a mixotrophic flagellate during bacterivory and autotrophy. Appl Environ Microbiol 60:1884-1888

Vadstein $O$, Harkjerr BO, Jensen A, Olsen Y, Reinertsen $\mathrm{H}$ (1989) Cycling of organic carbon in the photic zone of a eutrophic lake with special reference to the heterotrophic bacteria. Limnol Oceanogr 34:840-855

Weisse T, Müller H, Pinto-Coelho RM, Schweizer A, Springmann D, Baldringer G (1990) Response of the microbial loop to the phytoplankton spring bloom in a large prealpine lake. Limnol Oceanogr 35:781-794

Wetzel RG (1992) Gradient-dominated ecosystems: sources 
and regulatory functions of dissolved organic matter in freshwater ecosystems. Hydrobiologia 229:181-198 Williams PLeB (1990) The inportance of losses during micro-

Editorial responsibility: John Dolan,

Edgewater, Maryland, USA bial growth: commentary on the physiology, measurement and ecology of the release of dissolved organic material. Mar Microb Food Webs 4:175-206

Submitted: August 10, 1998; Accepted: May 6, 1999 Proofs received from author(s): October 7,1999 